\begin{tabular}{ccc}
\hline & International Journal of Current Research in \\
Biosciences and Plant Biology & Volume $5 \bullet$ Number 4 (April-2018) $\bullet$ ISSN: $2349-8080$ (Online) \\
\hline EXCELLENT \\
PUBLISHERS
\end{tabular}

\title{
Identification and Abundance of Indigenous Endomycorrhiza Isolated from Nickel Post-Mining Plantation in Sorowako
}

\section{Muhammad Akhsan Akib1, Kahar Mustari2 ${ }^{2}$ Tutik Kuswinanti ${ }^{3 *}$ and Syatrianty Andi Syaiful ${ }^{2}$}

${ }^{1}$ Graduate School, Hasanuddin University, Makassar, South Sulawesi, 90245, Indonesia; and Department of Agrotechnology, Faculty of Agriculture, Animal Husbandry and Fishery, Muhammadiyah University of Parepare, South Sulawesi, 91131, Indonesia

${ }^{2}$ Department of Agronomy Faculty of Agriculture, Hasanuddin University, Makassar, South Sulawesi-90245, Indonesia

${ }^{3}$ Department of Plant Pests and Diseases Faculty of Agriculture, Hasanuddin University, Makassar, South Sulawesi-90245, Indonesia

*Corresponding author.

\begin{tabular}{|c|c|}
\hline Article Info & \multirow{9}{*}{$\begin{array}{l}\text { Endomycorrhiza or arbuscular mycorrhiza has received tremendous attention due } \\
\text { toits ability to form a mutualistic symbiotic with } 80-96 \% \text { of plant species. } \\
\text { Therefore, the objectives of this study were to identify and to determine the } \\
\text { abundance of indigenous endomycorrhiza spores isolated from the nickel post- } \\
\text { mining plantation area in Sorowako. Quantitative-qualitative research was } \\
\text { conducted in two stages, which were; (1) Rhizosphere sampling of Morus alba and } \\
\text { Cyperus rotundus at nickel post-mining in Sumasang } 1 \text { area, rhizosphere of Wedelia } \\
\text { trilobutu and Melostoma affine in Sumasang } 2 \text { block A area, rhizosphere of Gleichenia } \\
\text { linearis and Equisetum gigatum in Sumasang } 2 \text { block B area, Sorowako village, East } \\
\text { Luwu Regency, South Sulawesi Province, Indonesia; (2) Isolation and identification } \\
\text { of spores Glomus sp., Acaulospora sp., and Gigasporas sp. were performed at the } \\
\text { Microbiology Laboratory, Research and Development Center for Environment and } \\
\text { Forestry Makassar, South Sulawesi.Based on the results, it had been found } 41.6- \\
63.6 \% \text { Acaulospora sp. spores with two layers of spore wall and average diameter of } \\
71.6 \mu m \text {; } 26.6-50.0 \% \text { Gigaspora sp. spores with one layer of spore wall and average } \\
\text { diameter of 232.7pm, and 8.3-13.3\% Glomus sp. spores with hypha remnant to } \\
\text { spore wall and average diameter of } 85 \mu \mathrm{m} \text { in Sumasang nickel post-mining } \\
\text { plantation area. }\end{array}$} \\
\hline $\begin{array}{l}\text { Date of Acceptance: } \\
23 \text { March } 2018\end{array}$ & \\
\hline $\begin{array}{l}\text { Date of Publication: } \\
\text { 06 April } 2018\end{array}$ & \\
\hline Keywords & \\
\hline Acaulospora & \\
\hline Gigaspora & \\
\hline Glomus & \\
\hline Indigenous & \\
\hline Micorrhiza & \\
\hline
\end{tabular}




\section{Introduction}

Plantation area of nickel (Ni) post-mining conducted by Vale Indonesia in Sorowakohas reached 3,975.9 ha in 2014 and 3,985.5 ha in 2015 with the total accumulation of planted trees was $1,859,107$ trees (Vale, 2015) which consists of several types of plants namely Paraserianthes falcataria, Eucalytus urograndis, Enterolobium macrocarpum, Melochia umbellata, Sandoricum kacappeae, Elmerelia sp, Ceiba pentandra, Acacia mangium, Mangifera indica, Adenanthera speciosa, Aleuritus molluccana, Cassia siamea and Casuarina sp with average growth reached $97 \%$ (Abubakar, 2009).

High percentage of plant growth can not be separated from the support of microorganisms symbiosis with plant roots, one of which is endomycorrhiza or arbuscular mycorrhiza (AM). Recently, AM has gained tremendous attention due to its ability to form a mutualistic symbiosis with $80 \%-96 \%$ of plant species although the effectiveness of its capabilities differs for each species (Wu et al., 2011; Prayudyaningsih and Sari, 2016).

A species of AMcan be symbiotic with a variety of plant species, vice versa, a plant species can be symbiotic with a variety of AM species (Tesitelova et al., 2013).

The symbiotic relationship between AM and plant root benefits to both, AM gains carbohydrates and energy from plant, while plant benefits from increased nutrient uptake especially $\mathrm{P}$ (Mau and Utami, 2014; Hosseini and Gharaghani, 2015), water level improvement and plant defence against drought stress (Sowmen et al., 2014; Augé et al., 2015), heavy metal stress (Bano and Ashfaq, 2013; Emamverdian et al., 2015), salinity stress (Yu et al., 2012; Fileccia et al., 2017), pathogenic diseases (Hemavani and Thippeswamy, 2014; Fauziyah et al., 2017), puddles (Marin's and Carrenho, 2017), and soil structure and aggregate improvement (Kimura and Scotti, 2016 ; Zhang et al., 2017). The role is strongly related to the formation of AM structures both in the roots and outside of plant roots (Smith and Smith, 2011; Smith et al., 2011).

Setiadi and Setiawan (2011) showed that Glomus sp. spores can be found in therhizospheres of Stemonurus celebicus, Calophyllum sp., Vitex coffasus, Weimannia blumei, Dillenia serrata, Eucalyptus urograndis, Ficus sp., Syzygium sp., Tectona grandis, Cassia siamea, Casuarina equisetifolia, Alstonia spectabilis, Maranthes corymbosa, Filicium decipiens, Malotus sp., Palaquium obovatum, Adenanthera pavonia, Paraserianthes falcataria, Enterolobium macrocarpum and Elmerillia tsiampacca. Spores of Acaulospora sp. can be found in the rhizospheres of Vitex coffasus, Dillenia serrata, Eucalyptus urograndis, Cassia siamea, Casuarina equisetifolia, Malotus sp., Paraserianthes falcataria, Enterolobium macrocarpum and Elmerillia tsiampacca; and spores of Gigaspora sp. are found in the rhizospheres of Ficus sp., Alstonia spectabilis, Eucalyptus urograndis, Cassia siamea, Casuarina equisetifolia, Paraserianthes falcataria and Enterolobium macrocarpum which grown in $\mathrm{Ni}$ post-mining in Sorowako. Furthermore, Setiadi and Setiawan (2011) showed that the average spore density of rhizosphere per $50 \mathrm{~g}$ samples from the nickel post-mining plantation area with dusty clay structurein the Fiona block is 253 spores, 122 spores in the Konde block, 50 spores in Deby block, 234 spores in the Petea block, and 209 spores in the Manggali block, whereas in the Nursery block with its sandy clay structure, it has been found 46 spores. However, this information does not indicate the abundance of AM spores of each genus.

In the gold post-mining location in West Lombok, Prasetyo et al. (2010) reported that few spores were found in tailing sites with clay particle content of $26.9 \%$ and $29.5 \%$ sand with $\mathrm{pH}$ of 5.4 , which were Glomus mossaeae and Scutellospora calospora from the rhizospheres of Acacia sp.; Glomus leptotichum and Glomus mossaeae from the rhizospheres of Gmelina sp.; Glomus deserticola, Glomus aggregatum, Glomus geosporum, and 
Glomus geosporumfrom the rhizospheres of Leucaena sp.; Glomus intraradices, Glomus mosaeae, and Glomus deserticola from the rhizosphere of Cassava.

In the lead mining area Angguran polluted by lead $(\mathrm{Pb})$ and zinc $(\mathrm{Zn})$ in Iran with clay particle content of $25.0-33.2 \%$, dust $45.0-59.0 \%$, sand $16-26 \%$ with $\mathrm{pH}$ of 7.5 - 7.9; Glomus versiforme, Gintraradices, G. mosseae in the rhizosphere of Veronica rechingeri had been found (Zarei et al., 2008). Similarly in the gold mining area of Morro do Ouro Brazil, which has $\mathrm{pH}$ of 3.9 to 6.6 with Arsenic (As) content of 10.2 - $1046.4 \mathrm{mg} \mathrm{dm}-3.23$ species of mycorrhizas were identified: 10 species of genus Acaulospora sp., 4 species of genus Scutellospora sp., 3 species of genus Racocetra $\mathrm{sp}$, 4 species of genus Glomus sp., 1 species of genus Gigaspora sp and Paraglomus sp. Glomus clarum, Paraglomus occultum and Acaulospora morrowiaeare the most common species found in areas contaminated by As. These three species together with Acaulospora mellea are the most abundant species in plant's rhizosphere grown in mining areas (Schneidera et al., 2013).

This study aimed to identify and to determine the abundance of indigenous endomycorrhiza in $\mathrm{Ni}$ post-mining in Sorowako as one of natural resources that can be utilized as biological agent in rehabilitation program.

\section{Materials and Methods}

This quantitative-qualitative study was conducted in two stages. First, rhizosphere sampling of Morus alba and Cyperus rotundus in nickel post-mining of Sumasang 1 (2031'48,7' S, 121022'40,9' E), rhizospheres of Wedelia trilobata and Melostama affine in the Sumasang 2 block A (2O31'58,6' S, 121022 '23,1" E) and rhizospheres of Gleichenia linearis and Equisetum gigantum in Sumasang Block B (2O31'58,1” S, 121O22'20,4” E), Sorowako village, East Luwu district, South Sulawesi, Indonesia, employing methods from Kumar (2012), Estrada et al. (2013) and Krishnamoorthy, (2015), as the first phase.
Sample soil analyzed in the Laboratory of Chemistry and Soil Fertility, Department Soil Science Faculty of Agriculture, Hasanuddin University, Makassar, Indonesia. Soil texture determinate with hydrometer method, $\mathrm{pH}$ of soil was measured with $\mathrm{pH}$ meter, $\mathrm{C}$-organic with Walkley and Black method, base cation (BC) with ammonium acetate extracted in $\mathrm{pH} 7$ then was measured with an atomic absorption spectrometer, Cation exchange capacity (CEC) with $1 \mathrm{M}$ NH4OAc, base saturation calculated with \% $\mathrm{BS}=($ bases cation/CEC) $\times 100 \%$. Concentration of soil nutrition was measured while in laboratory of chemistry, Polytechnic of Ujung Pandang, Makassar, using manual book of X-Ray Florence Spectrophotometer/Bruker/S2 Ranger. Characteristic of soil can be seen in Table 1.

The second phase was conducted at Microbiology Laboratory, Research and Development Center for Environment and Forestry, Municipality of Makassar, South Sulawesi, Indonesia. Arbuscular mycorrhiza (AM) spores were isolated from rhizosphere samples using pour and wet filtration technique by Gerdemann and Nicolson (1963) and sucrose centrifugation technique by Daniel and Skipper (1982). The number of spores per $100 \mathrm{~g}$ rhizosphere sample and spore diameter was measured using biomolecular microscope while spore morphological identification was determined using manual book from International Culture Collection of Vesicular Arbuscular Mycorrhizal Fungi (INVAM, 2016). The results of identification and abundance of AM spore population from each sample are shown in the form of tables and diagrams.

\section{Results and discussion}

The nickel post-mining plantation area in Sumasang has various plant vegetation which are different from one another, Sumasang 1 planting area is dominated bygrass vegetation, shrubs and naturally grown ferns and has shallow roots, prone to erosion and drought. As for the planting area of Sumasang 2 block $A$ and block $B$, in addition to vegetation grass, shrubs and ferns, it has been dominated by 
tree vegetation aged 5 to 10 years (Fig. 1). This strongly supports the development of indigenous AM which can not be separated from the development of the roots of host plants where the symbiotic association occurs. Abubakar (2009) reported that plant growth in $\mathrm{Ni}$ post-mining plantation has reached a greater percentage of success with more than $80 \%$ which is dominated by local plants that have adapted to marginal environment. The laboratory analysis results indicated that soil conditions in nickel postminingof Sumasang showed that the soil physical and chemical characteristics were not ideal. The rhizosphere sampling site is silty clay to clay loam with different percentages of sand, clay and dust content, slightly acidic soil $\mathrm{pH}$ due to very low $\mathrm{Al}$ elements (Table 1). However, according to Costa et al. (2013) and Bertham (2003), the optimum $\mathrm{pH}$ for spore development of Glomus sp. is 5.6 to 7 , Gigaspora sp. is 4.0 to 5.0 and Acaulospora sp. is 4 to 6 (Bertham, 2003), yet the optimum $\mathrm{pH}$ for the spore development is highly dependent on adaptability in high $\mathrm{Ni}$ concentration environment.

The content of $\mathrm{C}$ and organic material (OM) in nickel-post mining of Sumasang 2 belongs to medium criteria (Table 1). Organic material released by the roots is root exudate. Root exudate is requiredby microorganisms in its metabolism as source of energy or substrates in its activity, ingredients removed from living root cell activity such as sugars, amino acids, organic acids, fatty acids and sterols, nucleotides, flavonon, enzyme, and miscellaneous (Wihardjaka, 2010).

Several factors affect the amount and composition of exudates released by plants are plant species, plant age, environmental conditions (temperature, irradiation, soil moisture, soil type, plant nutrients, and stresspressure on plants), growing plants environmental conditions, and microorganisms presence (Budiyanto, 2015). Root secretion is material which actively pumped out of the roots (Sari, 2015), e.g., the mechanism of organic acid secretion (external mechanism) as a form of physiological response to $\mathrm{Al}$ in rice plants (Fajarwati, 2007). Root lycate is material passively pumped out while root cells autolysis occur (Sari, 2015) such as proteins, fats and amino acids. Root mucilage is the material of polysaccharides synthesized in the Golgi apparatus root cap cells move in vesicles through cytoplasm to plasmalema (Takehisa et al., 2012), e.g., root secretion material, epidermal cell remnant, root cap cells mixed with cell microbe remnant, metabolite products, organic colloids and inorganic colloids (Sari, 2015). The major enzymes produced by roots are oxidoreductase, hydrolase, liase, and transferase. The enzymes produced by microbes in the rhizosphere are cellulase, dehydrogenase, urease, phosphatase and sulfatase (Sudana, 2005).

Morphological identification of AM spores indicated the difference in shapes, colors and sizes of spores, which are divided into three groups of spores namely Acalauspora sp., Gigaspora sp., and Glomus sp. (Table 2), it is suspected that these three genera have wide adaptability in environment contains high nickel concentration. This results are similar to result findings of Setiadi and Setiawan (2011) that there are three major genera of AMin nickel post-mining plantation area namely Acaulospora sp., Glomus sp., and Gigaspora sp. The morphological identification results also show that the size of spores found on post mining land generally has a relatively small average diameter. According to INVAM (2016) the spores size for Acaulospora reaches average diameter of $74 \mu \mathrm{m}$ at Acaulospora rugosa to $289 \mu \mathrm{m}$ at Acaulospora foveata, Gigaspora reaches average diameter of $206 \mu \mathrm{m}$ at Gigaspora vosea to $358 \mu \mathrm{m}$ at Gigaspora decipiens, whereas for Glomus it reaches average diameter of $70 \mu \mathrm{m}$ on Glomus hoi to $220 \mu \mathrm{m}$ on Glomus lacteum.

The result of AM spore counting indicated that the diversity of three dominant AM generain percentage in Sumasang 1 area was $60.0 \%$ Acaulospora sp., 26.6\% Gigaspora sp., and $13.3 \%$ Glomus sp.; in Sumasang 2 block A area was50.0\% Gigaspora sp., 41.6\% Acaulospora sp., and 8.3\% Glomus sp.; while in Sumasang 2 Block B area was 63.6\% Acaulospora sp., 27.3\% Gigaspora sp. and 9.0\% Glomus sp. (Table 3). 

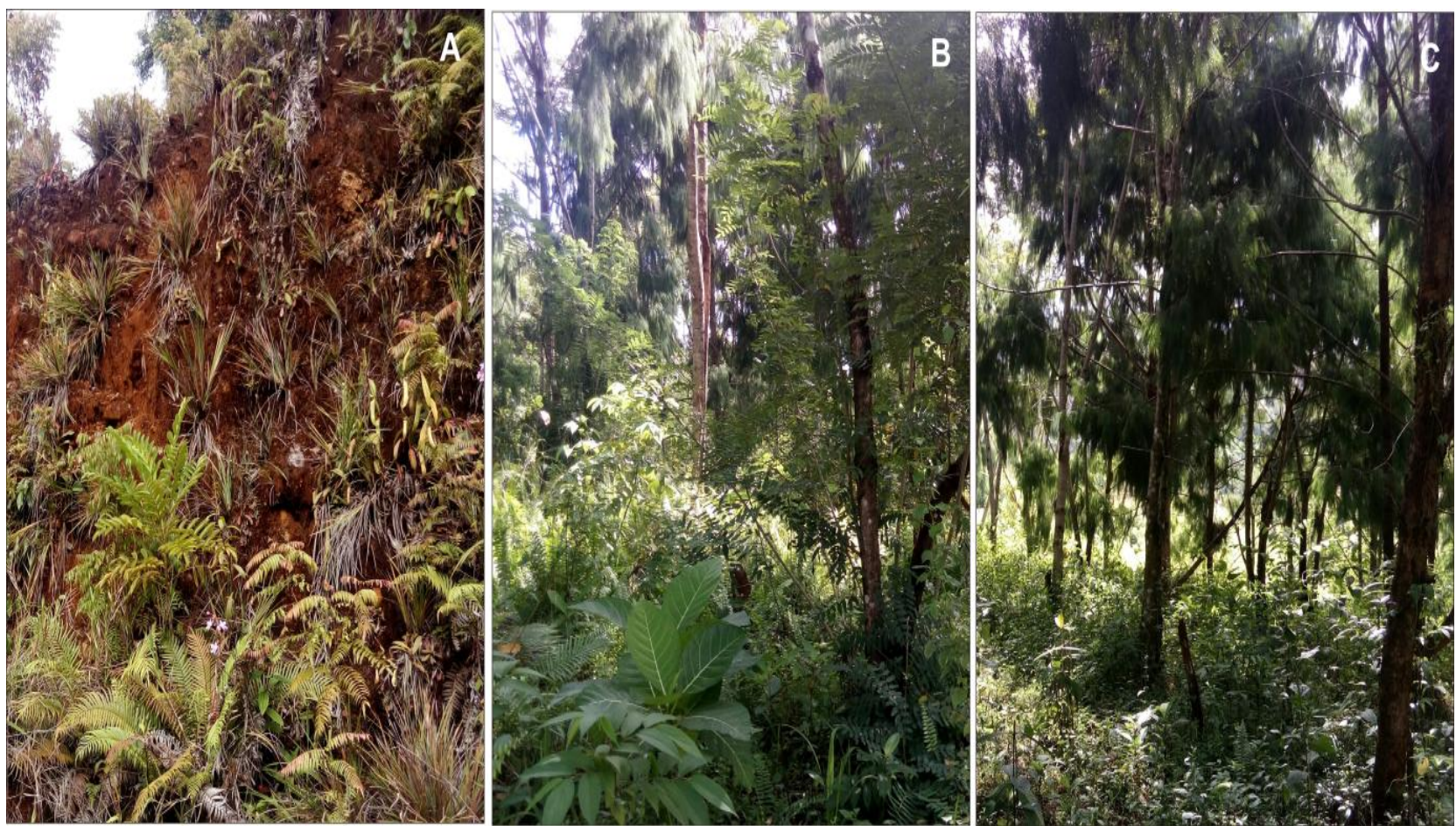

Fig. 1: Vegetation in nickel post-mining plantation Sumasang, Sorowako, South Sulawesi, Indonesia. $[(\mathrm{A})=$ Sumasang $1,(\mathrm{~B})=$ Sumasang 2 block $\mathrm{A},(\mathrm{C})=$ Sumasang 2 block B]

Table 1. Characteristic of soil and nutrient elements in nickel post-mining plantation area in Sumasang, Sorowako village, East Luwu district, South Sulawesi, Indonesia.

\begin{tabular}{llll}
\hline Characteristics & Location & & \\
\cline { 2 - 4 } & Sumasang 1 & Sumasang 2 block A & Sumasang 2 block B \\
\hline Pasir (\%) & 10 & 39 & 34 \\
Debu (\%) & 45 & 38 & 37 \\
Liat $(\%)$ & 45 & 23 & 45 \\
$\mathrm{pH}\left(\mathrm{H}_{2} \mathrm{O}\right)$ & 5.59 & 6.01 & 5.85 \\
$\mathrm{C}(\%)$ & 2.05 & 2.07 \\
$\mathrm{BO}$ & 1.97 & 3.53 & 3.57 \\
$\mathrm{KTK}\left(\mathrm{cmol}(+) \mathrm{kg}^{-1}\right)$ & 3.40 & 14.63 & 15.21 \\
$\mathrm{~KB}(\%)$ & 10.14 & 48 & 42 \\
$\mathrm{Al}(\mathrm{ppm})$ & 64 & $<1$ & $<1$ \\
$\mathrm{~K}(\mathrm{ppm})$ & $<1$ & $<8$ & $<8$ \\
$\mathrm{P}(\mathrm{ppm})$ & $<8$ & $<1$ & $<1$ \\
$\mathrm{Ni}(\mathrm{ppm})$ & $<1$ & 23.859 & 267 \\
\hline
\end{tabular}

M. A. Akib et al. (2018) / Identification and Abundance of Indigenous Endomycorrhiza Isolated from Nickel Post-Mining 
Table 2. Morphology of AM spores isolated from nickel post-mining plantation area in Sumasang, Sorowako, South Sulawesi, Indonesia.

\begin{tabular}{|c|c|c|c|c|}
\hline \multirow{2}{*}{ Location } & \multirow{2}{*}{ Spore Genera } & \multirow{2}{*}{ Morphology description } & \multicolumn{2}{|c|}{ Spore Diameter $(\mu \mathrm{m})$} \\
\hline & & & Identified & INVAM \\
\hline \multirow{4}{*}{ Sumasang 1} & Glomus sp. & $\begin{array}{l}\text { Round-shaped spore, has hypha } \\
\text { remnant, hialin colored, one layer of } \\
\text { spore wall. }\end{array}$ & $77.5 \times 77.5$ & 70 to 220 \\
\hline & Gigaspora s & $\begin{array}{l}\text { Round-shaped spore, light yellow } \\
\text { colored,one layer of spore wall, } \\
\text { smooth surface unornamented. }\end{array}$ & $203 \times 203$ & 206 to 358 \\
\hline & Acaulo & $\begin{array}{l}\text { Round-shaped spore, yellowy brown } \\
\text { colored, two layersof spore wall with } \\
\text { inner wall, the color of its center is } \\
\text { darker then the outer }\end{array}$ & $60 \times 60$ & 74to 289 \\
\hline & Glomus sp. & $\begin{array}{l}\text { Round-shaped spore, has hypha } \\
\text { remnant, hialin colored, one layer of } \\
\text { spore wall. }\end{array}$ & $82.5 \times 82.5$ & 70 to 220 \\
\hline \multirow[t]{3}{*}{$\begin{array}{l}\text { Sumasang } 2 \\
\text { Block A }\end{array}$} & Gigaspora sp & $\begin{array}{l}\text { Round-shaped spore, cream yellow } \\
\text { colored, one layer of spore } \\
\text { wall,smooth surface unornamented. }\end{array}$ & $260 \times 260$ & 206 to 358 \\
\hline & Acaul & $\begin{array}{l}\text { Round-shaped spore, yellowy brown } \\
\text { colored, two layersof spore wall with } \\
\text { inner wall, the color of its center is } \\
\text { darker then the outer }\end{array}$ & $80 \times 80$ & 74 to 289 \\
\hline & Glomus sp. & $\begin{array}{l}\text { Round shape spore, has no hypha } \\
\text { remnant, hialin colored, one layer of } \\
\text { spore wall }\end{array}$ & $95 \times 95$ & 70 to 220 \\
\hline \multirow[t]{2}{*}{$\begin{array}{l}\text { Sumasang } 2 \\
\text { Block B }\end{array}$} & Gigaspora s & $\begin{array}{l}\text { Round-shaped spore, dark yellow } \\
\text { colored, one layer of spore wall, } \\
\text { smooth surface, has Bulbous } \\
\text { Suspensor trace }\end{array}$ & $235 \times 235$ & 206 to 358 \\
\hline & Acaulospora sp. & $\begin{array}{l}\text { Round-shaped spore,two layersof } \\
\text { spore wall with inner wall, the color } \\
\text { of its center is darker then the outer }\end{array}$ & $75 \times 75$ & 74 to 289 \\
\hline
\end{tabular}


Table 3. Number of mycorrhizal spores per $100 \mathrm{~g}$ of rhizosphere samples.

\begin{tabular}{llllll}
\hline \multirow{2}{*}{ Location } & \multirow{2}{*}{ Rhizosphere } & \multirow{2}{*}{ Family } & \multicolumn{2}{l}{ Number of spores } \\
\cline { 4 - 6 } & Morus alba & Moraceae & 1 & GGS & ACS \\
\hline \multirow{2}{*}{ Sumasang 1} & Cyperus rotundus & Cyperaceae & 1 & 1 & 6 \\
& Wedelia trilobata & Asteraceae & 1 & 1 & 2 \\
\hline Sumasang 2 & Melostama affine & Melastomataceae & 0 & 5 & 3 \\
Block A & Gleichenia linearis & Gleicheniaceae & 0 & 1 & 5 \\
\hline Sumasang 2 & Equisetum gigantum & Equisetaceae & 2 & 5 & 9 \\
Block B & S &
\end{tabular}

Note: GLS, Glomus sp.; GGS, Gigaspora sp.; ACS, Acaulospora sp.

There are two hypotheses to support the dominance of Acaulospora sp abundance in the high nickel concentration (Table 1), first: Acaulospora sp. has two layers of cell wall, which can become aberrant and spore defense organ against the nickel heavy metal stress. According to Galli et al. (1993), most heavy metals are bound and stored in spore cell wall components such as chitin, cellulose, cellulose derivatives and melanin. Stronger defence allows the spore tolerance of Acaulospora sp. to be higher than spores of Gigaspora sp. and Glomus sp. It provides wider opportunity for faster adaptation process of Acaulospora sp. to reach domestication stage, is another hypothesis. As for Gigaspora sp. and Glomus sp. which have only one layer of cell wall, it is suspected that the hypha spore is place where heavy metals are bound, Andrade and Silveira (2008) and Aloui et al. (2011) stated that metals can be precipitated or chelated in the soil matrix through glycoproteins production or produce phosphatemamin complexes in hypha, yet hypha growth is strongly influenced by environmental factors. Suharno et al. (2013) suggested that the adaptation is related to the gradual changes of microbial community structures, based on gradual changes in community structures over fatty acid phospholipid profile affects more tolerant organisms.

The development and utilization of the more dominant indigenous mycorrhizas is unexploited natural resource for nickel post-mining rehabilitation program in Sorowako, South Sulawesi, Indonesia. Syib'li et al. (2013) suggested that high abundance of mycorrhiza in field can be used as the phytoremediation of soil fertility, since
AM has high interaction with organic material, total phosphorus, and cation exchange capacity.

The number of spores in nickel post-mining plantation area at Sumasang showed $55.1 \%$ Acaulospora sp., 34.6\% Gigaspora sp. and $10.2 \%$ Glomus sp., with diameter of $60 \mu \mathrm{m} \times 60 \mu \mathrm{m}$ to 260 $\mu \mathrm{m} \times 260 \mu \mathrm{m}$. The dominant indigenous mycorrhiza was Acaulospora sp which has two layers of spore wall as heavy metal storage organ. Therefore, this species has higher tolerance in high nickel concentration environment which is the natural wealth resource of Sorowako village which can be developed as biological agent for nickel post-mining land rehabilitation program.

\section{Conflict of interest statement}

Authors declare that they have no conflict of interest.

\section{Acknowledgment}

Acknowledgments given to Vale Indonesia and Center for Research and Development of Environment and Forestry Makassar for their support and guidance in completing this research.

\section{References}

Abubakar, F., 2009. Evaluasi tingkat keberhasilan revegetasi lahan bekas tambang nikel di PT.Inco Tbk. Sorowako, Sulawesi Selatan. Skripsi Fakultas Kehutanan. Institut Pertanian Bogor. Aloui, A., Recorbet, G., Robert, F., Schoefs, B., 
Bertrand, M., Henry, C., Pearson, V.G., Gaudot, E.D., Smiti, S.A., 2011. Arbuscular mycorrhizal symbiosis elicits shoot proteome changes that are modified during cadmium stress alleviation in Medicago truncatula. BMC Plant Biol. 11(75), 1-17.

Andrade, S.A.L.D., Silveira, A.P.D.D., 2008. Mycorrhiza influence on maize development under $\mathrm{Cd}$ stress and $\mathrm{P}$ supply. Braz. J. Plant Physiol. 20(1), 39-50.

Bano, S.A., Ashfaq, D., 2013. Role of mycorrhiza to reduce heavy metal stress. Natural Sci. 5(12A), 16-20.

Bertham, R.Y.H., 2003. Purification techniques of monoxenic VAM culture using Petridisk and test tube methods. J. Ilmu-Ilmu Pertan. Indonesia. 5(1), 18-26.

Budiyanto, G., 2015. Interaksi Biologi Nitrogen Dalam Tanah. Makalah Kuliah Umum Program Studi Agroteknologi Fakultas Pertanian Universitas Muhammadiyah Yogyakarta.

Costa, F.A., Haddad, L.S.M., Kasuya, M.C.M., Oton, W.C., Costa, M.D., Borges, A.C., 2013. In vitro culture of Gigaspora decipiens and Glomus clarum in transformed roots of carrot: The influence of temperature and $\mathrm{pH}$. Acta Sci. Agron. 35(3), 315-323.

Emamverdian, A., Ding, Y., Mokhberdoran, F., Xie, Y., 2015. Heavy metal stress and some mechanisms of plant defense response. Scient. World J. 2015(2015), Article ID 756120, 18 pages.

Fajarwati, I., 2007. Organic Acid Secretion On AlStressed Rice. Departemen Biologi Fakultas Matematika Dan Ilmu Pengetahuan Alam. Institut Pertanian Bogor.

Fauziyah, N., Hadisutrisno, B., Suryanti., 2017. The roles of arbuscular mycorrhizal fungi in the intensity of the foot rot disease on pepper plant from the infected soil. J. Degr. Mining Lands Manag. 4(4), 937-943.

Fileccia, V., Ruisi, P., Ingraffia, R., Giambalvo, D., Frenda, A.S., Martinelli, F., 2017. Arbuscular mycorrhizal symbiosis mitigates the negative effects of salinity on durum wheat. PLoS One. 12(9), e0184158.

Hemavani, C., Thippeswamy, B., 2014. Effect of arbuscular mycorrhizal fungus, Acaulospora lacunosa on growth of groundnut disease caused by Cercospora arachidicola. Int. J. Res. Appl. Natural Social Sci. 2(4), 57-60.

Hosseini, A., Gharaghani, A., 2015. Effects of arbuscular mycorrhizal fungi on growth and nutrient uptake of apple rootstocks in calcareous soil. Int. J. Horticult. Sci. Technol. 2(2), 173-185.

INVAM, 2016. International Culture Collection of Vesicular Arbuscular Mycorrhizal Fungi. http://invam.caf.wvu.edu.

Kimura, A.C., Scotti, M.R., 2006. Soil aggregation and arbuscular mycorrhizal fungi as indicators of slope rehabilitation in the Sao Francisco River Basin (Brazil). Soil Water Res. 11(2), 114-123.

Krishnamoorthy, R., Kim, C.G., Subramanian, P., Kim, K.P., Selvakumar, G., Sa, T.M., 2015. Arbuscular mycorrhizal fungi community structure, abundance and species richness changes in soil by different levels of heavy metal and metalloid concentration. PLoS One. 10(6), e0128784

Kumar, R., Tapwal, A., Silva, J.A.T., Pandey, S., Borah, D., 2012. Diversity of arbuscular mycorrhizal fungi associated in a mixed natural forest of Jeypore, Assam. Bioremed. Biodiv. Bioavail. 7(1), 91-93.

Marins, J.Fd., Carrenho, R., 2017. Arbuscular mycorrhizal fungi and dark septate fungi in plants associated with aquatic environments. Acta Bot. Bras. 31(2), 295-308.

Mau, A.E., Utamim, S.R., 2014. Effects of biochar amendment and arbuscular mycorrhizal fungi inoculation on availability of soil phosphorus and growth of maize. J. Degraded Mining Lands Manage. 1(2), 69-74.

Prasetyo, B., Krisnayanti, D.D., Utomo, W.H., Anderson, C.W.N., 2010. Rehabilitation of artisanal mining gold land in West Lombok, Indonesia: 2. Arbuscular mycorrhiza status of tailings and surrounding soils. J. Agric. Sci. 2(2), 202-209.

Prayudyaningsih, P., Sari, R., 2016. The application of arbuscular mycorrhizal fungi (AMF) and compost to improve the growth of teak seedlings (Tectona grandis Linn. F.) on 
limestone post-mining soil. J. Penel. Kehut. Wall. 5(1), 37-46.

Sari, D.R., 2015. Isolation and identification of soil bacteria around plant roots. Bio-Site. 1, 21-27.

Schneidera, J., Stürmerb, J.S.L., Guilhermea, L.R.G., Moreiraa, F.M.S., Claudio Soaresc, R.F.S., 2013. Arbuscular mycorrhizal fungi in arsenic-contaminated areas in Brazil. J. Haz. Mat. 262, 1105-1115.

Setiadi, Y., Setiawan, A., 2011. Studi status fungi mikoriza arbuskula di areal rehabilitasi pasca penambangan nikel (studi kasus PT. INCO Tbk. Sorowako, Sulawesi Selatan). J. Silv. Trop. 3(1), 88-95.

Smith, S.E., Jakobsen, I., Gronlund, M., Smith, F.A., 2011. Roles of arbuscular mycorrhizas in plant phosphorus nutrition: Interactions between pathways of phosphorus uptake in arbuscular mycorrhizal roots have important implications for understanding and manipulating plant phosphorus acquisition. Plant Physiol. 156, 1050-1057.

Smith, S.E., Smith, F.A., 2011. Roles of arbuscular mycorrhizas in plant nutrition and growth: New paradigms from cellular to ecosystem scales. Annu. Rev. Plant Biol. 62, 227-250.

Sudana, W., 2005. Pemanfaatan mikrobia pelarut fosfat dan mikoriza untuk perbaikan fosfor tersedia, serapan fosfor Tanah Ultisol dan Hasil Jagung pada Ultisol. J. Ilmu-Ilmu Pertan. Indonesia. 6(1), 8-13.

Syib'li, M.A., Muhibuddin, A., Djauhari, S., 2013. Arbuscular mycorrhiza fungi as an indicator of soil fertility. Agrivita. 35(1), 44-53.

Takehisa, H., Sato, Y., Igarashi, M., Abiko, T., Antonio, B.A., Kamatsuki, K., Minami, H.,Namiki, N., Inukai, Y., Nakazono, M.,
Nagamura, Y., 2012. Genome-wide transcriptome dissection of the rice root system: Implications for developmental and physiological functions. Plant J. 69(1), 126-140.

Tesitelova, T., Jersakova, J., Roy, M., Kubatova, B., Tesitel, J., Urfus, T., Travncek, P., Suda, J., 2013. Ploidy-specific symbiotic interactions: divergence of mycorrhizal fungi between cytotypes of the Gymnadenia conopsea group (Orchidaceae). New Phytol. 199(4), 1022-1033.

Vale, 2015. Sustainability report, unwavering commitment. PT. Vale Indonesia Tbk.

Wihardjaka, A., 2010. Emisi gas dinitrogen Oksida dari Tanah Sawah Tadah Hujan yang diberi Jerami Padi dan Bahan Penghambat Nitrifikasi. J. Biol. Indonesia. 6(2), 211-224.

Wu, Q.S., Li, G.H., Zou, Y.N.,2011. Roles of arbuscular mycorrhizal fungi on growth and nutrient acquisition of peach (Prunus persica $\mathrm{L}$. Batsch) seedlings. J. Anim. Plant Sci. 21(4), 746-750.

Yu, Z.X., Zhang, Q., Yang, H.S., Tang, J.J., Weiner, J., Chen, X., 2012. The effects of salt stress and arbuscular mycorrhiza on plant neighbor effects and self-thinning. Basic Appl. Ecol. 13(8), 673-680.

Zarei, M., Konig, S., Hempel, S., Nekouei, H.K., Savaghebi, Gh., Buscot, F., 2008. Community structure of arbuscular mycorrhizal fungi associated to Veronica rechingeri at the Anguran zinc and lead mining region. Environ. Poll. 156(3), 1277-1283.

Zhang, Y.C., Wang, P., Wu, Q.H., Zou, Y.N., Bao, Q., Wu, Q.S., 2017. Arbuscular mycorrhizas improve plant growth and soil structure in trifoliate orange under salt stress. Arch. Agron. Soil Sci. 63(4), 491-500.

\section{How to cite this article:}

Akib, M. A., Mustari, K., Kuswinanti, T., Syaiful, S, A., 2018. Identification and abundance of indigenous endomycorrhiza isolated from nickel post-mining plantation in Sorowako. Int. J. Curr. Res. Biosci. Plant Biol. 5(4), 8-16. doi: https://doi.org/10.20546/ijcrbp.2018.504.002 